\title{
Development of a SYBR green real-time PCR method for rapid detection of sheep pox virus
}

\author{
Hong Tian', Jingyan $\mathrm{Wu}^{2}$, Yan Chen ${ }^{3}$, Keshan Zhang ${ }^{4}$, Youjun Shang ${ }^{4}$ and Xiangtao Liu ${ }^{3 *}$
}

\begin{abstract}
Background: In this study, we developed a SYBR Green-based real-time PCR assay for the detection of sheep pox virus using a plasmid construct carrying one of the highly conserved genes encoding the virion envelope protein (P32) as a template.

Results: The method was demonstrated to be highly sensitive, allowing a precise SPV DNA quantitation over a range of nine orders of magnitude (from $10^{1}$ to $10^{9}$ copies of standard DNA). Then, specimens from SPV suspected sheep were analyzed by conventional gel-based PCR, real-time PCR and sequence analysis.

Conclusion: Comparison between these different techniques revealed that real-time PCR is more sensitive than conventional gel-based PCR, allowing detection low viral titers of SPV in infected sheep.
\end{abstract}

Keywords: Sheep pox virus, SYBR Green I based quantitative PCR

\section{Background}

Sheep pox (SP) is malignant diseases of small ruminants causing heavy economic loss in the endemic countries $[1,2]$. The causative agents, sheep pox and goat pox viruses, belong to the genus Capripoxvirus in the family Poxviridae $[3,4]$. The diseases are endemic in India, Bangladesh, throughout the near and middle east, northern and central Africa [5].

Prompt detection of sheep pox virus (SPV) in the field samples is important for effective SPV control, thereby reducing the potentially serious economic damage which can result from an outbreak [6]. Because of the isolation of virus in cell cultures is technically difficult and timeconsuming, so it is not a suitable routine diagnostic tool. Therefore, A rapid, specific and sensitive assays are required for the diagnosis of SPV. The aims of this study were to develop a rapid and sensitive method, able to detect a wide range of field samples of SPV in a feasible way in a short time.

\section{Results and discussion}

SYBR green real-time PCR amplification was carried out with Mx3005P Real-Time PCR System (Agilent

\footnotetext{
* Correspondence: hnxiangtao@163.com

${ }^{3}$ Lanzhou Veterinary Research Institute, Yanchangbu, Xujiaping, Lanzhou

730046, China

Full list of author information is available at the end of the article
}

Stratagene, USA) and the data were analyzed with MxPro $^{\text {TM }}$ QPCR System (version 4.10). Duplicates of the SPV standard dilutions and DNA templates were simultaneously subjected to real-time analysis. After 40 amplification cycles, a melting analysis was carried out to verify the correct product by its specific melting temperature $(\mathrm{Tm})$. The optimal annealing temperature was $57{ }^{\circ} \mathrm{C}$, whereas optimal primer concentrations were $0.4 \mu \mathrm{M}$. The results were analyzed using MxPro ${ }^{\mathrm{TM}} \mathrm{QPCR}$ Software and Tm values were taken to verify the specificities of the PCR products.

In order to evaluate the reproducibility, a dilution endpoint standard curve was made and repeated for three times. Ct values were measured in triplicate and plotted against the amount of plasmid copy number (Figure 1). The standard formula was $y=-3.528 x+15.60$ and the correlation co-efficient was 0.999 . The diluted plasmid pMD-P32 was positive for a $10-8$ dilution $(\mathrm{Ct}=38.65)$, indicating a sensitivity of the method being 10 copy numbers per reaction mixture. No primer-dimers or non-specific amplification product were visible for negative samples (Figure 2).

To assess the use of the real-time PCR for the detection of viral DNA in the clinical samples. Seven of these 26 samples were found to be positive by conventional PCR, ten of 26 samples were found to be positive by real-time PCR. All samples identified positive by 


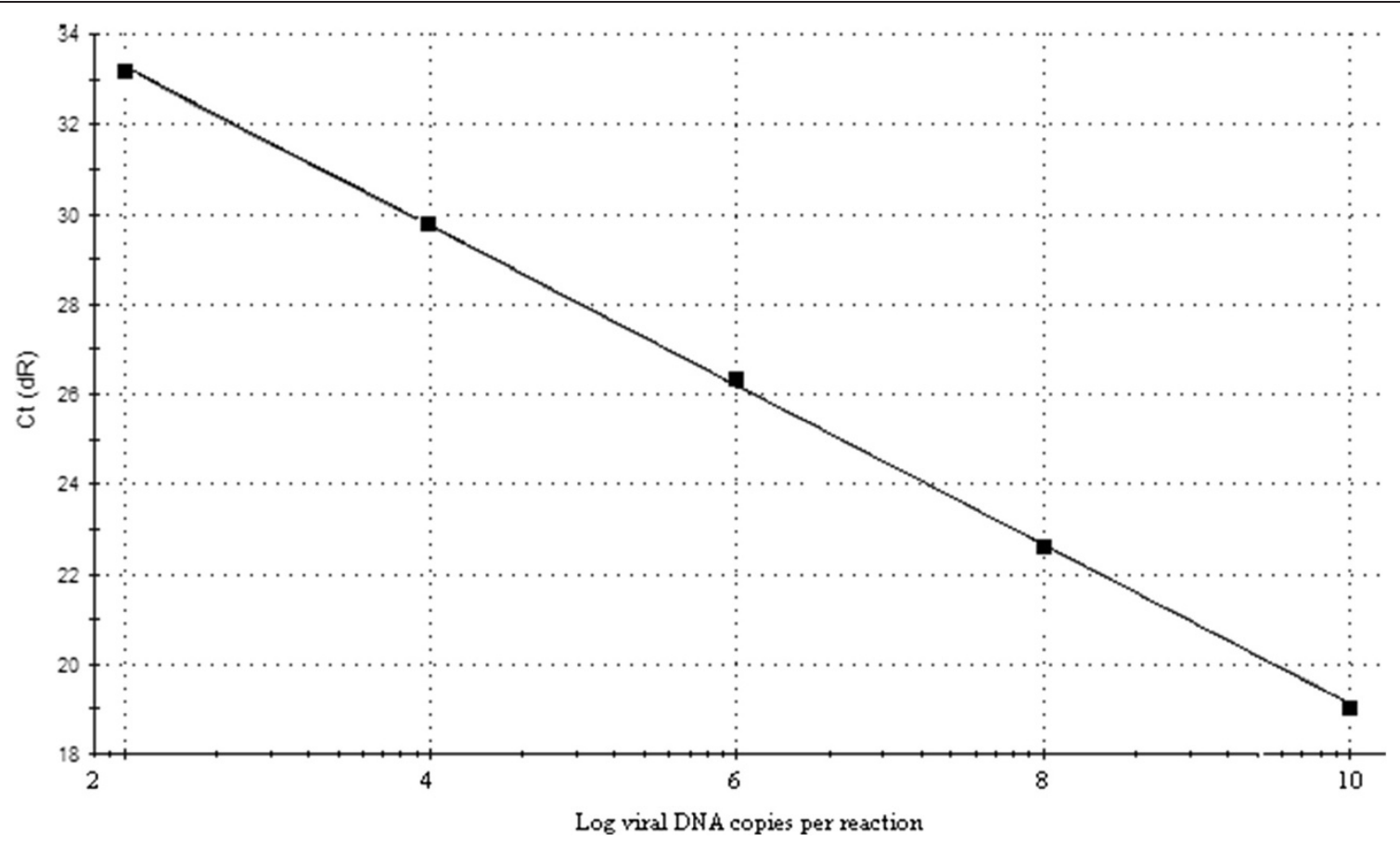

Figure 1 Standard curve (plot of the $C_{\mathrm{T}}$ values against the different P32 plasmid DNA concentrations), showing a linear relationship between plasmid concentration and threshold cycles. The standard formula is $y=-3.528 x+15.60$ and the correlation co-efficient is 0.999 .

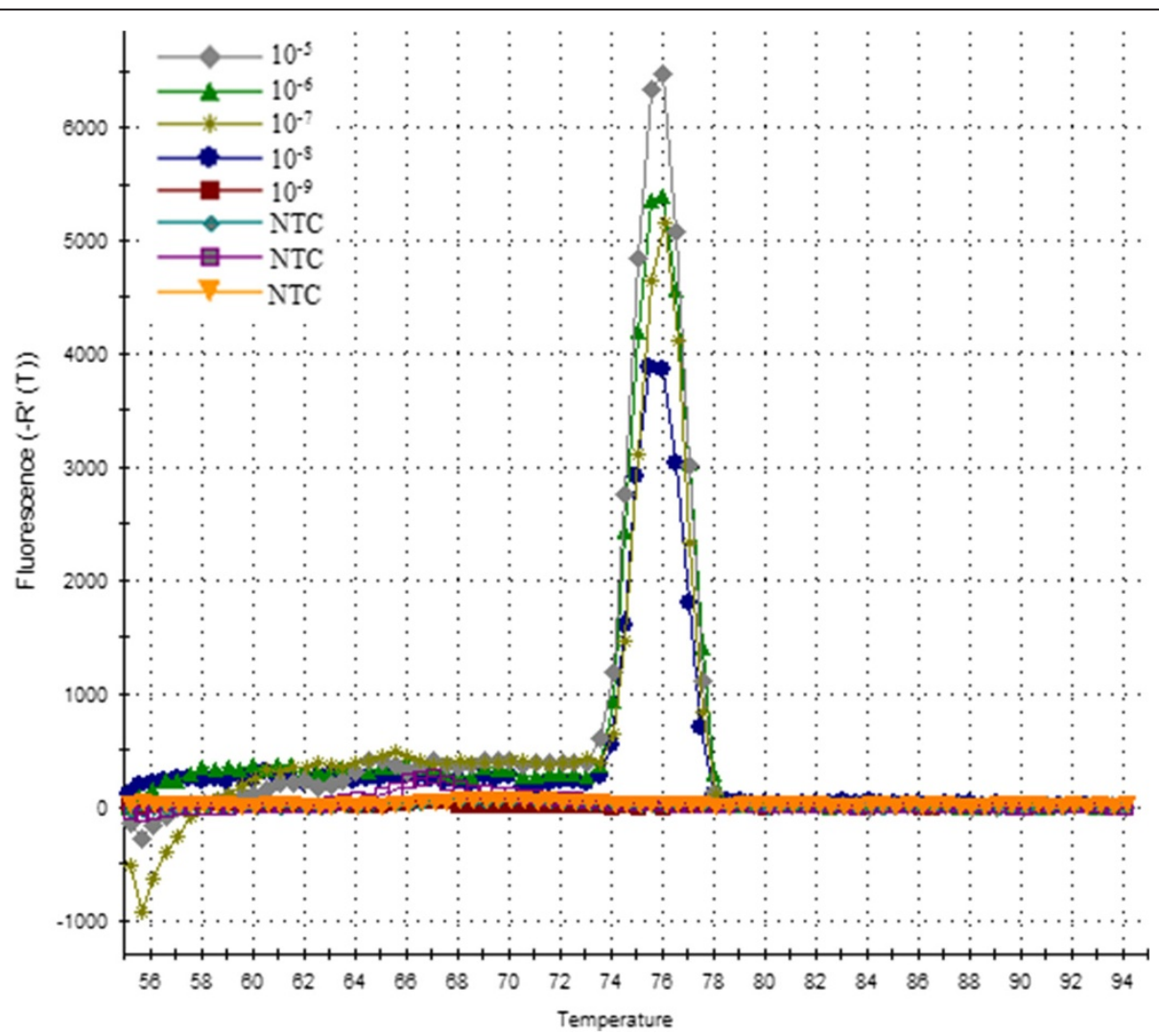

Figure 2 The dissociation plot of amplified plasmid P32 DNA. Melting peaks of P32 plasmid DNA ten-fold serial dilutions and negative control, the positive samples showed an identical melting curve profile. 
conventional PCR and real-time PCR were confirmed to be SPV by sequence analysis.

Real-time PCR assays have been widely utilized for early diagnosis of many other animal viral diseases $[7,8]$. In this study a real-time PCR assay was developed and evaluated for detection of SPV in field samples. The assay described in this report generates complete result in $1.5 \mathrm{~h}$ and can be used as a rapid diagnostic tool.

To improve the sensitivity of the method described it was necessary to optimize the conditions of primers and annealing temperature. With these parameters, the detection of the plasmid P32 could be up to a $10^{-8}$ dilution. This method does not require post-PCR manipulation because the melt curve data allow to verifying amplification products, thus diminishing the potential contamination risk. No primer-dimers were observed in the amplification products when analysed by melting curve. Under the above conditions, it was possible to establish a sensitivity of 10 copy numbers per reaction mixture.

\section{Conclusion}

Considering the prevalence and economic impact of SPV, a simple, cost-effective, sensitive and rapid diagnostic technique is very important. The SYBR green realtime PCR assay described in this study has all these attributes. This technique has applications in routine diagnostics in common laboratories.

\section{Materials and methods}

In this study, 26 field samples (scars) were collected from SPV suspected animals during 2009 in China during general surveillance. Samples were placed at $-70^{\circ} \mathrm{C}$ for further use. The DNA of all field samples was extracted using QIAamp DNA Mini Kit (Cat. No.51306, Qiagen).

The primers used for real-time PCR amplification of SPV were designed using sequence data from the SPV P32 protein gene, and the primer will dilution into different concentration (final concentration, 0.2, 0.4, 0.6, or $0.8 \mu \mathrm{M})$. The partial sequence of the P32 gene of SPV was downloaded from GenBank (accession no. AY159333) and aligned (using Clustal W program in the MegAlign Package (DNAStar)) with the available P32 gene sequences of other strains of SPV to identify the conserved regions. Primers were designed and synthesized target on conserved regions (Table 1). The routine PCR reaction mixture containing the amplified $900 \mathrm{bp}$ products was cloned into the pMD18-T Vector (TaKaRa Code, D101A). The plasmid P32 DNA was used as PCR standard template for the determination of the standard curve and sensitivity of the real-time PCR. After DNA quantitation by NanoDrop ND-2000 analysis, 10-fold dilutions of the plasmid, representing $10^{0}-10^{9}$ copies of DNA $/ 10 \mu \mathrm{L}$ of template, were used to carrying out the
Table 1 Oligonucleotide primers designed for SPV amplification by conventional gel-based PCR and real-time PCR

\begin{tabular}{llll}
\hline Primer & Sequence $\left(\mathbf{5}^{\prime}-\mathbf{3}^{\prime}\right)$ & Length & \\
\cline { 3 - 4 } & & Primer $\mathbf{( b p )}$ & Product $\mathbf{( b p )}$ \\
\hline $\mathrm{Nf}$ & GGGGGATATGATITACCTTA & 21 & $235^{\mathrm{a}}$ \\
$\mathrm{Nr}$ & ATATACCGTITTCATTCGTTAG & 24 & \\
$900 \mathrm{f}$ & TTATATGTTATACCAATCGTTGGTC & 25 & $900^{\mathrm{b}}$ \\
$900 \mathrm{r}$ & TAACATACCTGCTAAAAACCAT & 22 & \\
\hline
\end{tabular}

a Length of product amplified by real-time PCR primer pair.

${ }^{b}$ Length of product amplified by conventional PCR primer pair.

standard curve and the sensitivity of developed real-time PCR methods. Each dilution were frozen at $-70^{\circ} \mathrm{C}$ and used only once.

\section{Competing interests}

None of the authors of this paper has a financial or personal relationship with other people or organizations that could inappropriately influence or bias the content of the paper (including National Modern Meat Caprine Industrial Technology System).

\section{Authors' contributions}

HT participated in design experiments and drafted the manuscript. JYW and YC carried out the experiments. KSZ and YJS conceived of the study. XTL participated in its design and coordination. All authors read and approved the final manuscript.

\section{Acknowledgements}

This work was sponsored by National Modern Meat Caprine Industrial Technology System (nycytx-39).

\section{Author details}

${ }^{1}$ State Key Laboratory of Veterinary Etiological Biology, Lanzhou 730046, China. ${ }^{2}$ National Foot and Mouth Disease Reference Laboratory, Lanzhou 730046, China. ${ }^{3}$ Lanzhou Veterinary Research Institute, Yanchangbu, Xujiaping, Lanzhou 730046, China. ${ }^{4}$ Chinese Academy of Agricultural Sciences, Lanzhou 730046, China.

Received: 30 November 2011 Accepted: 12 October 2012 Published: 27 November 2012

\section{References}

1. Afshar A, Bundza A, Myers DJ, Dulac GC, Thomas FC: Sheep pox: experimental studies with a West African isolate. Can Vet J 1986, 27:301-306.

2. Bhanuprakash V, Indrani BK, Hosamani M, Singh RK: The current status of sheep pox disease. Comparative Immunology. Micr Infect Dis 2006, 29:27-60.

3. Babiuk S, Bowden TR, Parkyn G, Dalman B, Manning L, Neufeld J, EmburyHyatt C, Copps J, Boyle DB: Quantification of lumpy skin disease virus following experimental infection in cattle. Transbound Emerg Dis 2008, 55:299-307.

4. Tuppurainen ES, Venter EH, Coetzer JA: The detection of lumpy skin disease virus in samples of experimentally infected cattle using different diagnostic techniques. J Vet Res 2005, 72:153-164.

5. Babiuk S, Bowden TR, Boyle DB, Wallace DB, Kitching RP: Capripoxviruses: an emerging worldwide threat to sheep, goats and cattle. Transbound Emerg Dis 2008, 55:263-272.

6. Mangana-Vougiouka O, Markoulatos P, Koptopoulos G, Nomikou K, Bakandritsos N, Papadopoulos P: Sheep poxvirus identification from clinical specimens by PCR, cell culture, immunofluorescence and agar gel immunoprecipitation assay. Mol Cell Probe 2000, 14:305-310 
7. Agüero M, Sánchez A, San Miguel E, Gómez-Tejedor C, Jiménez-Clavero MA: A real-time TaqMan PCR method for neuraminidase type 1 (N1) gene detection of H5N1 Eurasian strains of avian influenza virus. Avian Dis 2007, 51 (1 Suppl):378-381.

8. Shaw AE, Reid SM, Ebert K, Hutchings GH, Ferris NP, King DP: Implementation of a one-step real-time PCR protocol for diagnosis of foot-and-mouth disease. J Virol Methods 2007, 143(1):81-85.

doi:10.1186/1743-422X-9-291

Cite this article as: Tian et al:: Development of a SYBR green real-time PCR method for rapid detection of sheep pox virus. Virology Journal 2012 9:291.

\section{Submit your next manuscript to BioMed Central and take full advantage of:}

- Convenient online submission

- Thorough peer review

- No space constraints or color figure charges

- Immediate publication on acceptance

- Inclusion in PubMed, CAS, Scopus and Google Scholar

- Research which is freely available for redistribution 